\title{
Be Well Informed: A Web Tool for Private Well Owners
}

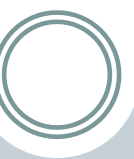

\section{PIERCE RIGROD,}

NEW HAMPSHIRE

DEPT OF ENVIRONMENTAL SERVICES

DRINKING WATER \& GROUNDWATER BUREAU

$$
\text { (603-271-0688) }
$$

\section{PIERCE.RIGROD@DES.NH.GOV}

Funding to complete NH's Be Well Informed was provided by a grant from the US Centers for Disease Control in 2013 


\section{Private Wells \& Public Health}

Low-to-moderate levels of arsenic in drinking water and bladder cancer risk.

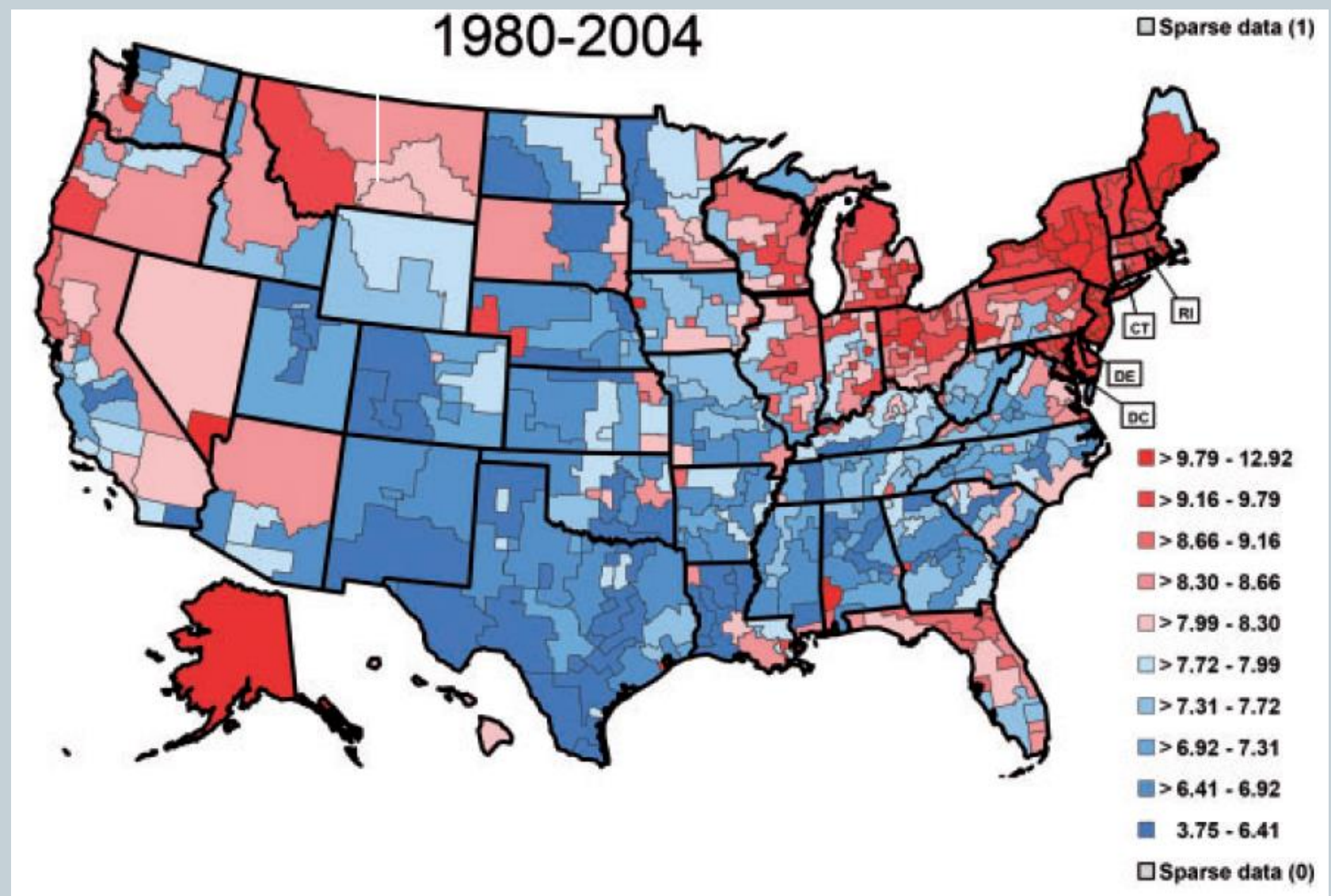

Elevated Bladder Cancer in Northern New England: The Role of Drinking Water and Arsenic, J Natl Cancer Inst (2016) 


\section{Purpose of Be Well Informed}

- Interpret lab results in terms of water quality standards

$\circ$ Provide treatment guidance concerning treatment technologies

○ Provide information on health and home appliance impacts 


\section{Private Wells: The NH Rundown}

Private wells serve $46 \%$ of New Hampshire's population, $\sim 520,000$ people.

No uniform testing or treatment requirement(s) for private wells in New Hampshire.

New Hampshire has abundant groundwater, generally free from harmful anthropogenic contaminants 


\section{Probable Exposure \& Estimated Morbidity}

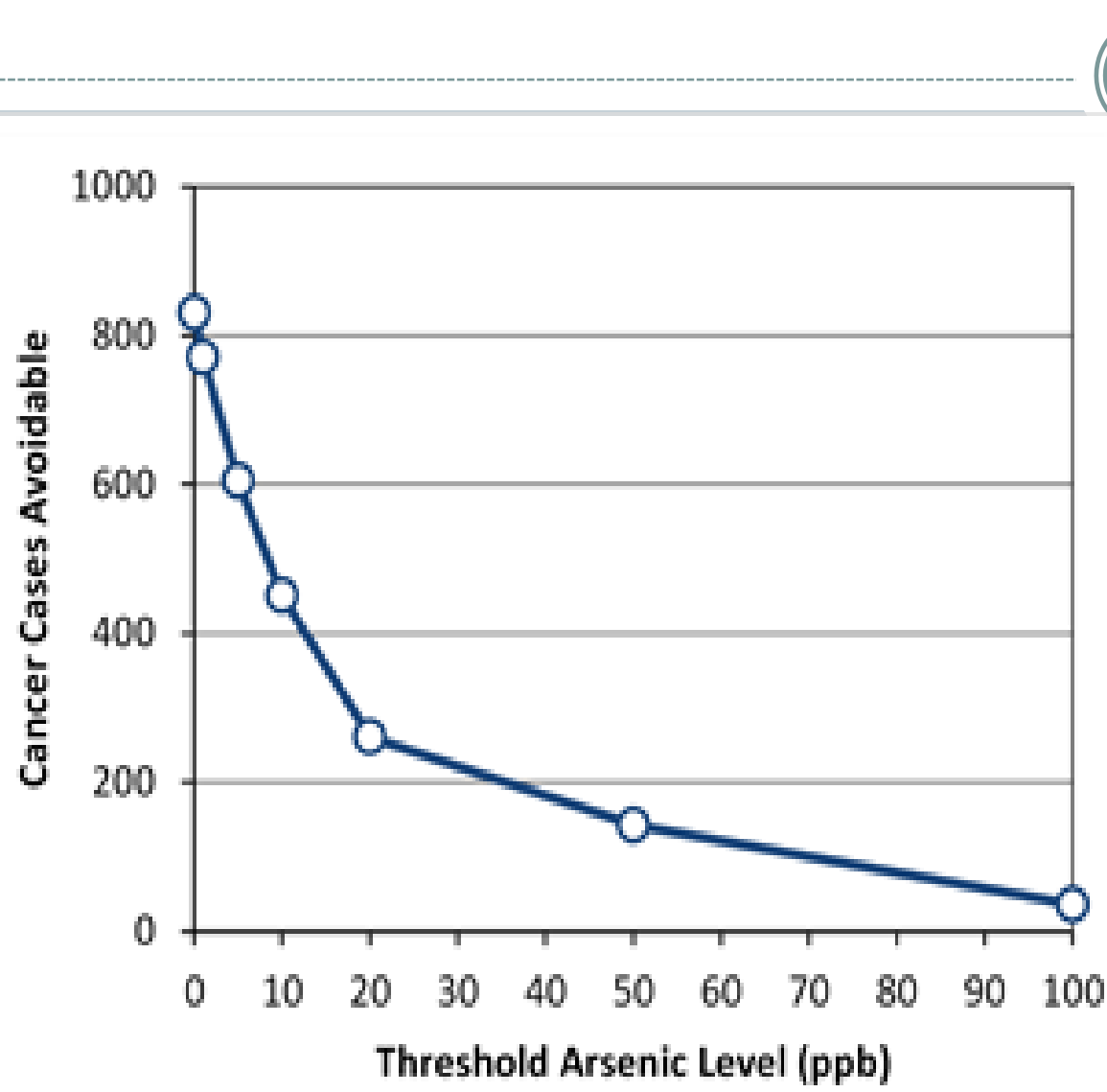

Figure 3 . The estimated number of bladder, lung and non-melanoma skin cancers avoidable by removing arsenicfrom well water down to a range of threshold levels from 0 to $100 \mathrm{ppb}$.

\section{ZUSGS}

Prepared in cooperation with the

New Hampshire Department of Health and Human Services and the

New Hampshire Department of Environmental Services

\section{Estimated Probability of Arsenic in Groundwater} from Bedrock Aquifers in New Hampshire, 2011
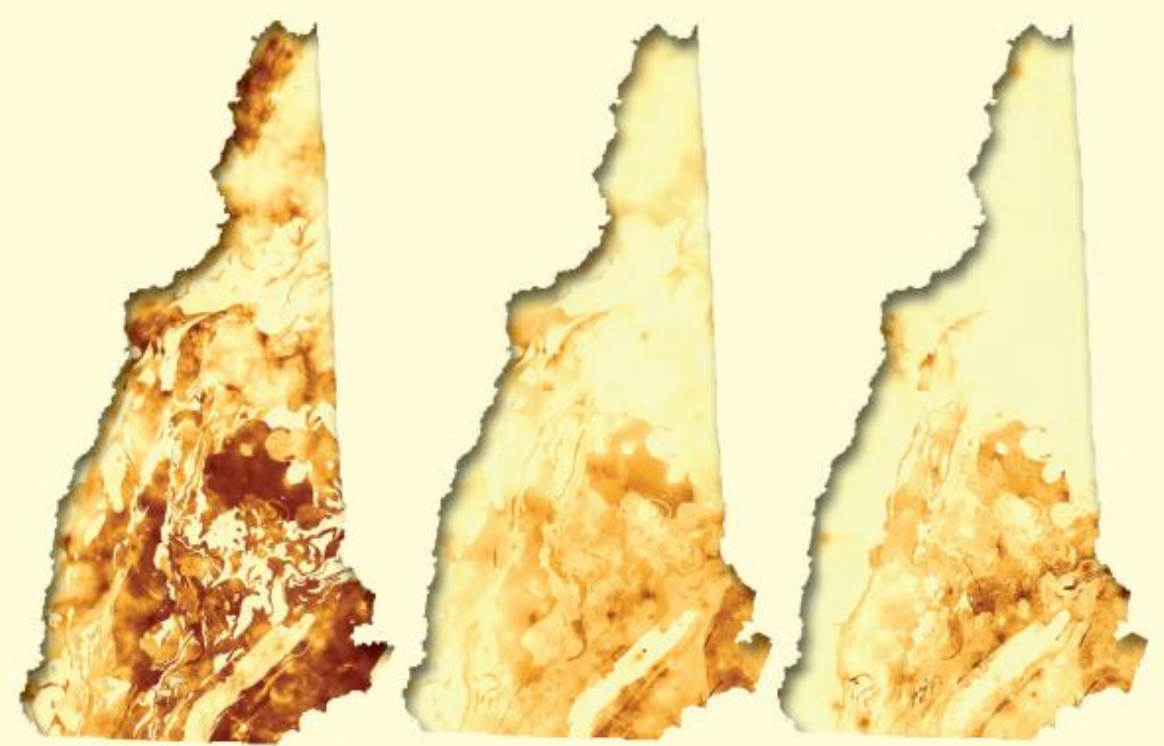

Scientific Investigations Report 2012-5156 


\section{Health Impacts - Arsenic}

Low dose, chronic, long term exposure to Arsenic in drinking water can lead to:

- Cancers (bladder, skin, kidney, liver, prostate and lung)

- Vascular and cardiovascular disease

- Reproductive and developmental effects

- Cognitive and neurological effects

- Diabetes and other metabolic disorders

- Neuropathy 


\section{Statewide Averages:}

\section{Estimated \% of Private Wells Above MCL}

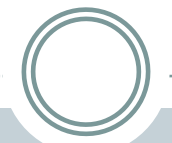

\% Private Wells > Drinking Water Limits (NH)

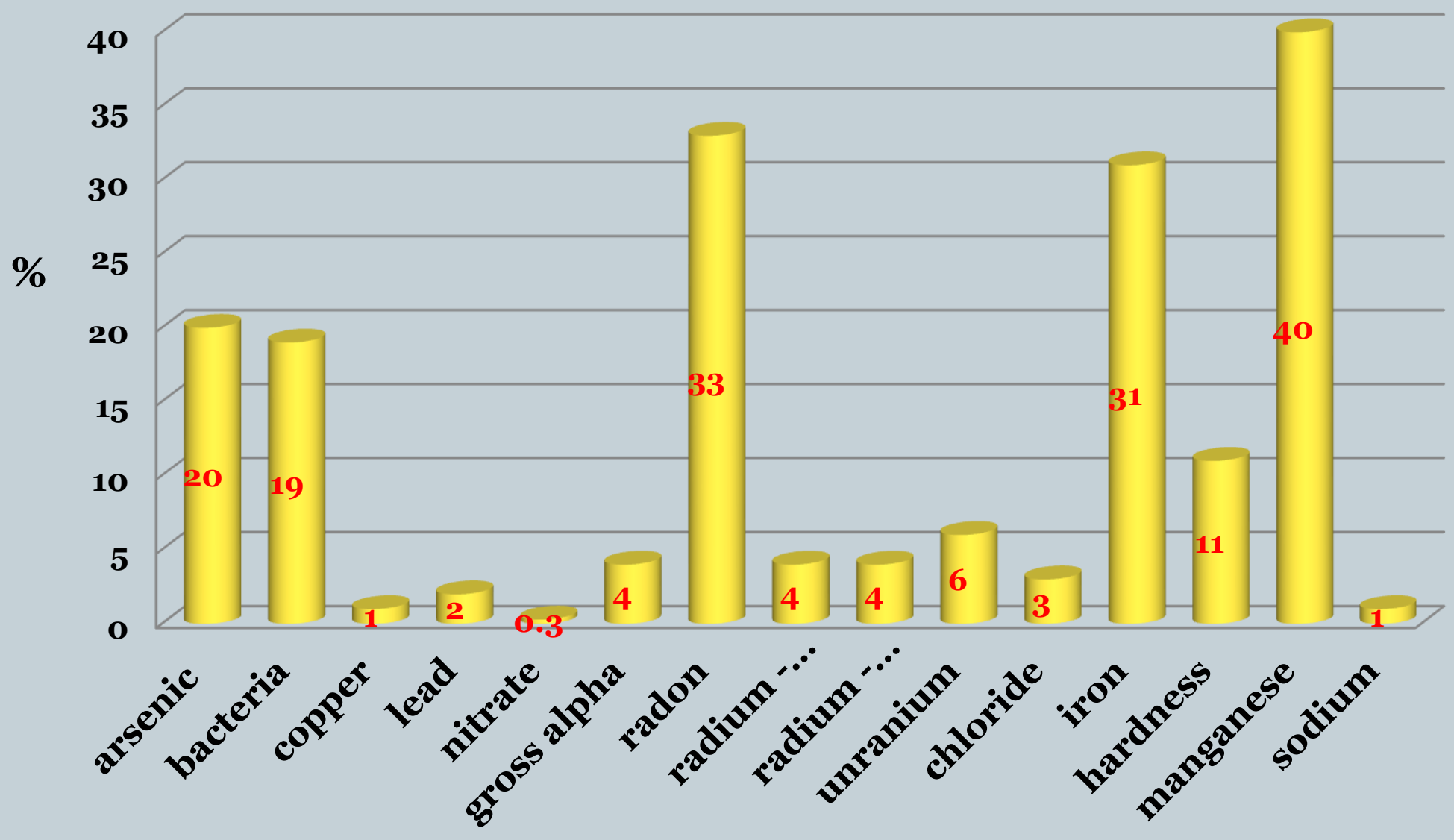

Pct Above Limit 


\section{$\%$ of Samples Exceeding Recommended Limit}

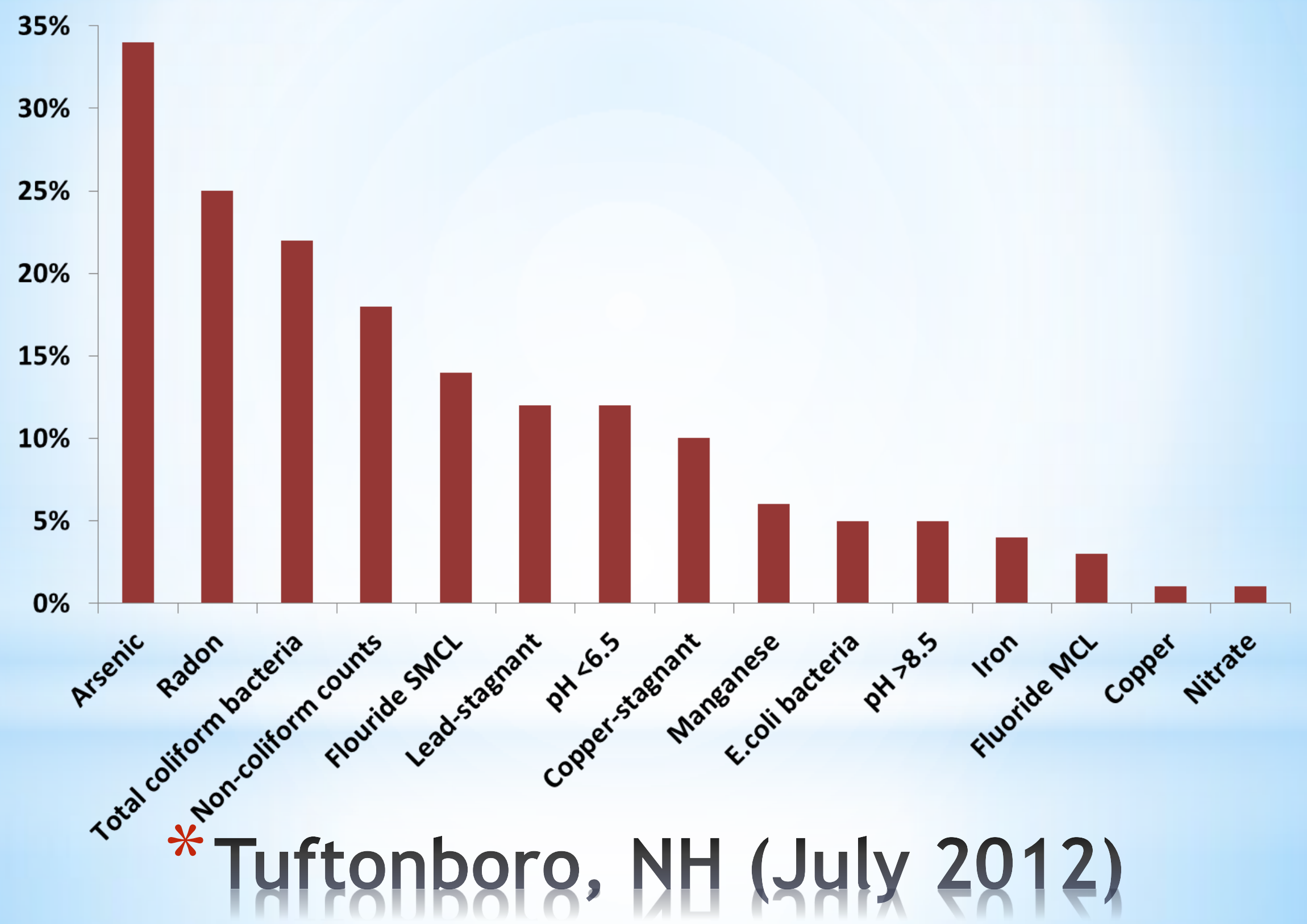




\section{Many Questions, Many Choices}

(37\%) of residents surveyed in $\mathrm{NH}$ in 2014 were not clear about what actions to take after receiving water test results.
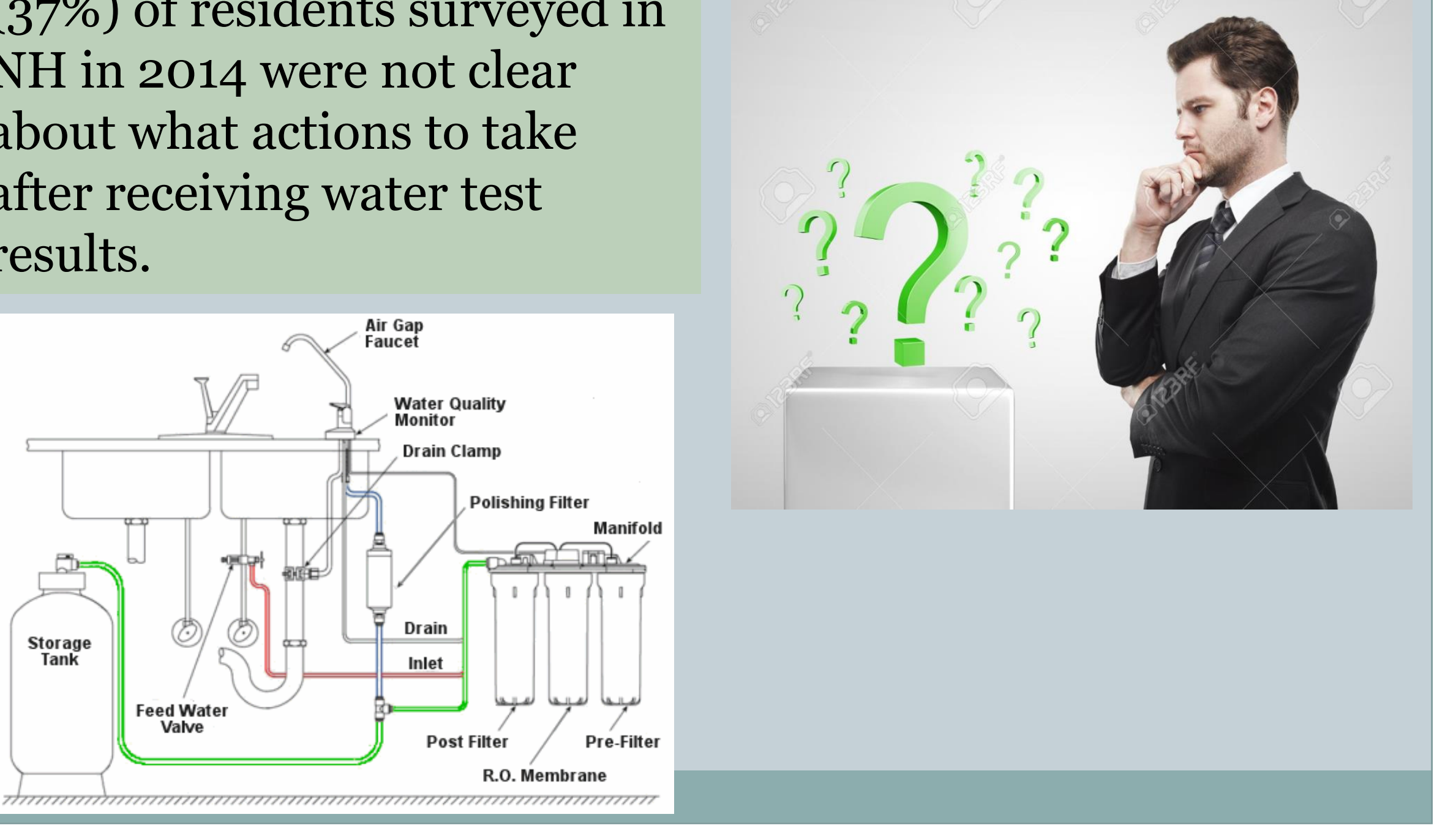


\section{Many Residents Not Selecting Proper Treatment}<smiles>C1=CC=CC=CC=1</smiles>

\section{Improper treatment Range: $9.5 \%$ to $93.8 \%$}

$\mathrm{N}=178$

$45.5 \%$ mistreat rate

(81 out of 178 )

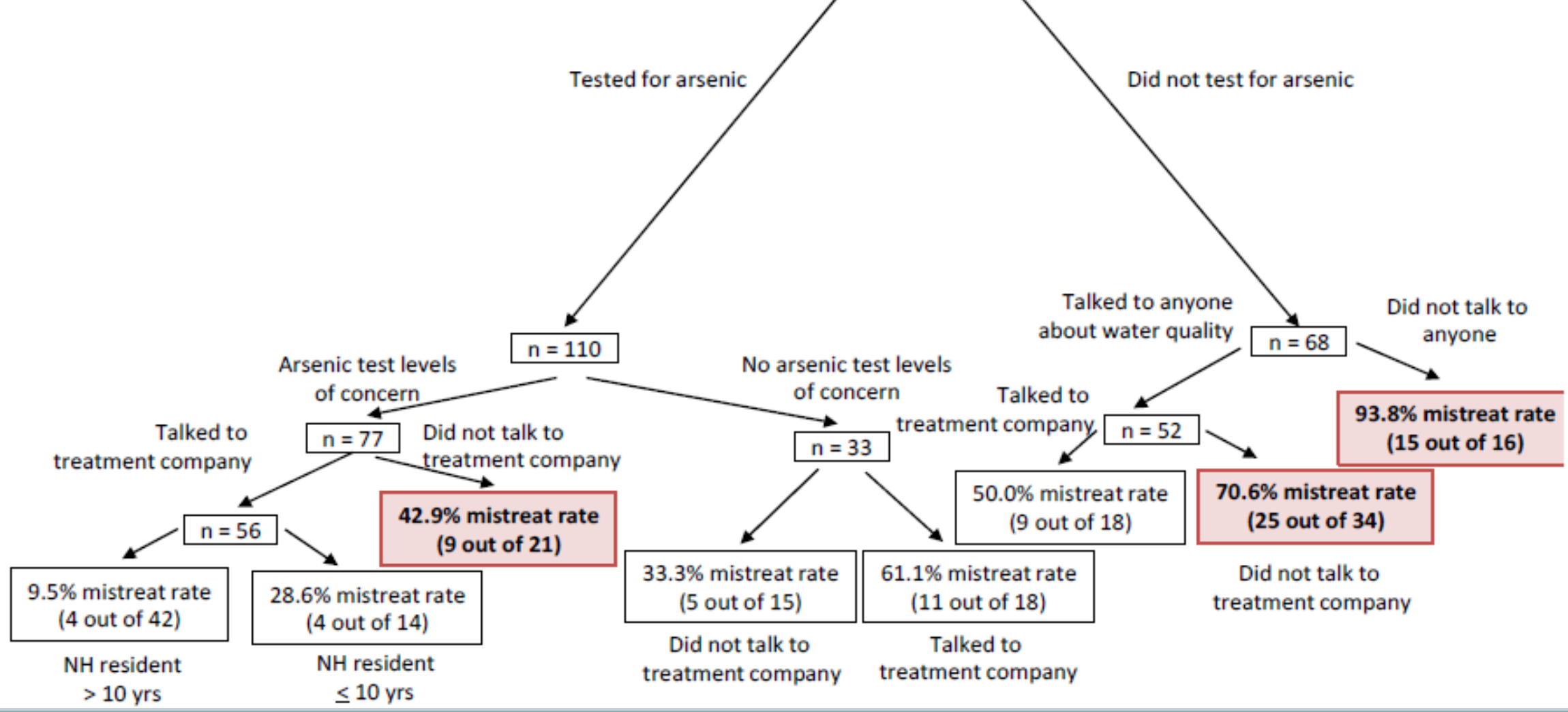




\section{BWI Inputs (Lab Report)}

$(())$

( Invalid Entry - Please try again

$\rightarrow$ Routine Water Analysis

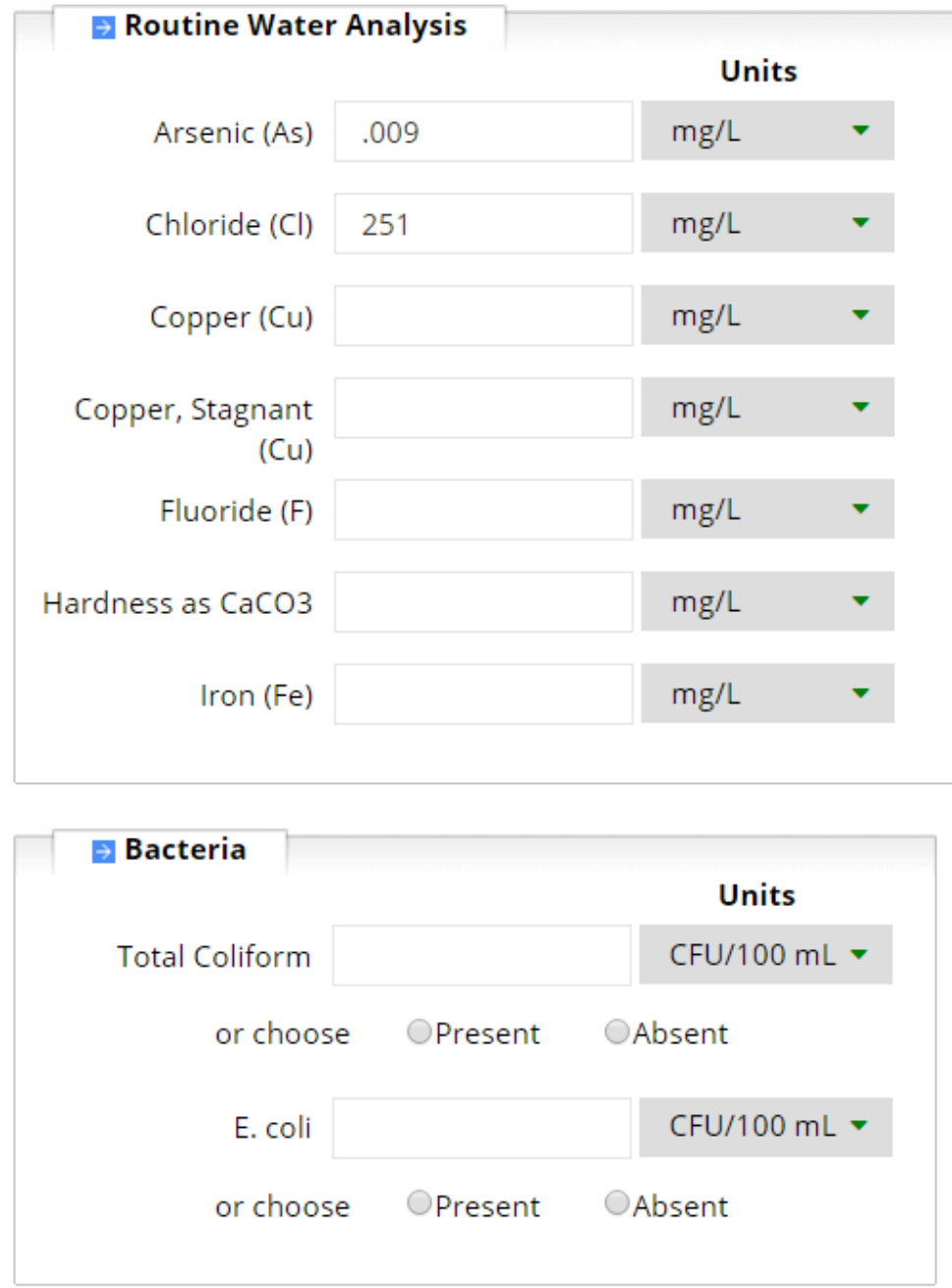

NH Town or City *

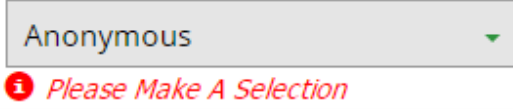

(i) Please Make A Selection

\begin{tabular}{|c|c|c|c|}
\hline & & \multicolumn{2}{|c|}{ Units } \\
\hline Lead $(\mathrm{Pb})$ & .016 & $\mathrm{mg} / \mathrm{L}$ & $\boldsymbol{\nabla}$ \\
\hline Lead, Stagnant (Pb) & & $\mathrm{mg} / \mathrm{L}$ & $\boldsymbol{\nabla}$ \\
\hline Manganese (Mn) & & $\mathrm{mg} / \mathrm{L}$ & $\nabla$ \\
\hline Nitrate-N & 11 & $\mathrm{mg} / \mathrm{L}$ & $\boldsymbol{\nabla}$ \\
\hline Nitrite-N & 1.1 & $\mathrm{mg} / \mathrm{L}$ & $\boldsymbol{\nabla}$ \\
\hline $\mathrm{pH}$ & & units & $\nabla$ \\
\hline Sodium (Na) & & $\mathrm{mg} / \mathrm{L}$ & $\nabla$ \\
\hline
\end{tabular}




\section{As Water Treatment Logic}

\section{BWI has 17 treatment logic charts - One for each Contaminant}

${ }^{1}$ Numeric Value Entry and Defoult Unit

\section{User Entry for} Arsenic

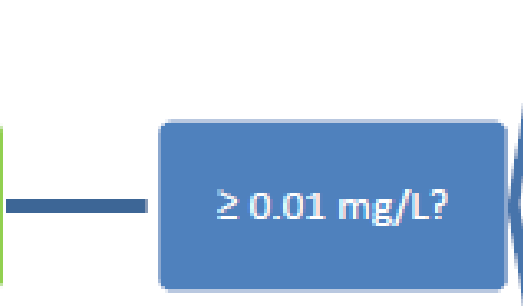

\section{LEGEND}

Starting Point for Parameter's Logic Model

Logic

Pop-Up Question for User

Treatment Suggestion

1 Numeric values in flow charts will be adjusted in accordance with the units specified by the user. Default units of measure for arsenic will be $\mathrm{mg} / \mathrm{L}$.

2

\section{A Pop-Up message will appear on the screen, posing a question to the user, and the answer will be}

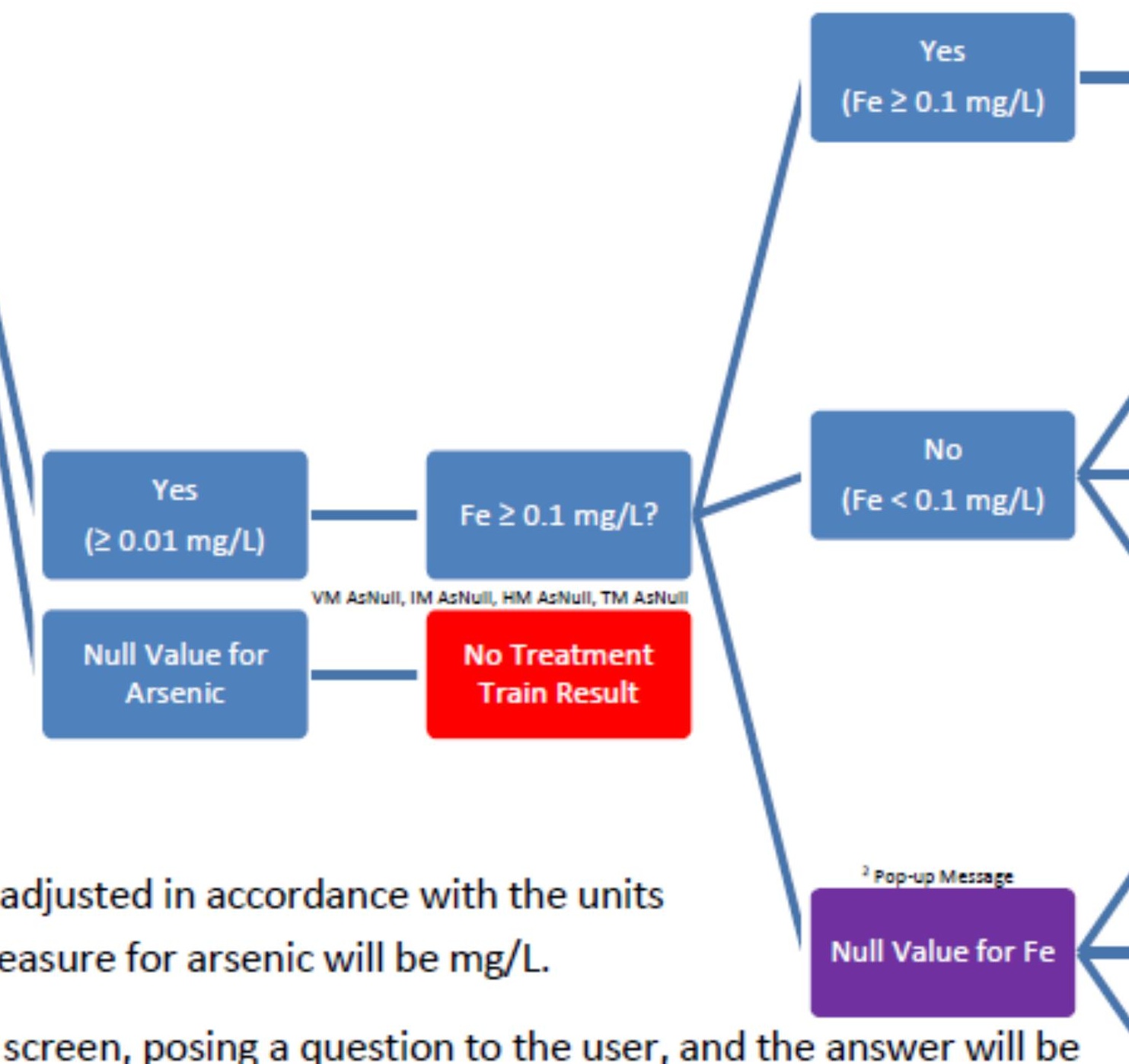




\section{User Questions (“Pop ups”)}

To receive the best treatment recommendation, please enter the following water quality values.

Please enter the value for Iron (symbol is "Fe") if there is a result within your lab report. If Iron was not tested as part of your $\mathrm{mg} / \mathrm{L}$ water analysis, leave the box blank. Do not enter " 0 ".

Does your water taste salty?

Prompts (pop-ups) help to ensure all contaminant information is entered to ensure best treatment recommendations 


\section{BWI User "Outputs"}

\section{Recommends appropriate treatment technologies, $\underline{\text { not }}$ products.}

"Part 1 Results Summary" interprets water quality data

Easy to understand text and graphics

- Part 2 Provides a dynamic "treatment train"

Graphic showing one or more treatments in sequence

- Part 3 Short narratives on health/home impacts

* Yields printable PDF reports

Provides links and offers phone support from DES 


\section{Printable Web App Report: Part 1: "Results Summary"}

Click Here To Start Over

Results Summary

Value entered meets the Drinking Water Limit.
Value entered is close to the Drinking Water Limit.
Value entered exceeds the Drinking Water Limit.

\begin{tabular}{|c|c|c|c|}
\hline$\Delta$ Routine Analysis & Water Test Value Entered & $\begin{array}{l}\text { Drinking Water Contaminant Limit } \\
\text { or Radon Advisory Level }\end{array}$ & ? About Your Well Water? \\
\hline Arsenic & $.011 \mathrm{mg} / \mathrm{L}$ & $0.01 \mathrm{mg} / \mathrm{L}$ & $\begin{array}{l}\text { The value entered exceeds the } \\
\text { drinking water standard }\end{array}$ \\
\hline Iron & $.2 \mathrm{mg} / \mathrm{L}$ & $0.3 \mathrm{mg} / \mathrm{L}$ & $\begin{array}{l}\text { The value entered meets the } \\
\text { drinking water guideline }\end{array}$ \\
\hline Lead Stagnant & $.15 \mathrm{mg} / \mathrm{L}$ & $0.015 \mathrm{mg} / \mathrm{L}$ & $\begin{array}{l}\text { The value entered exceeds the } \\
\text { drinking water standard }\end{array}$ \\
\hline Manganese & $400 \mathrm{mg} / \mathrm{L}$ & $0.05 \mathrm{mg} / \mathrm{L}$ & $\begin{array}{l}\text { The value entered exceeds the } \\
\text { drinking water guideline }\end{array}$ \\
\hline Nitrite-N & $2 \mathrm{mg} / \mathrm{L}$ & $1 \mathrm{mg} / \mathrm{L}$ & $\begin{array}{l}\text { The value entered exceeds the } \\
\text { drinking water standard. } \\
\text { YOUR WATER IS NOT SAFE } \\
\text { FOR BABIES UNDER SIX } \\
\text { MONTHS OLD TO CONSUME. }\end{array}$ \\
\hline
\end{tabular}




\section{Part 2: Treatment "Train"}

(

\section{Recommended Water Treatment To Remove Arsenic, Lead Stagnant, Manganese}

The following recommended water treatment is based on the water quality information you entered. Details concerning water treatment are below.

\section{Treatment Order}

\begin{tabular}{|c|c|c|c|c|c|c|c|c|}
$\begin{array}{c}\text { Whole House Oxidizing } \\
\text { Filter System }\end{array}$ & OR & $\begin{array}{c}\text { Whole House Cation } \\
\text { Exchange Water } \\
\text { Softener }\end{array}$ \\
\hline
\end{tabular}

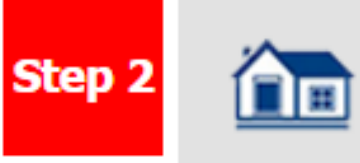

Whole House Acid

Neutralizer System

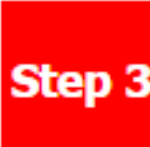

Point-of-Use (POU) Arsenic Adsorption Media Filter System

Point-of-Use (POU)

OR System 


\section{Part 3: Interpretation, Health, Treatment}

\section{Results Detail}

$\checkmark$ Value entered meets the Drinking Water Limit. $\quad$ \ Value entered exceeds the Drinking Water Limit.

! Value entered is close to the Drinking Water Limit. $\odot$ A Value was Not Entered

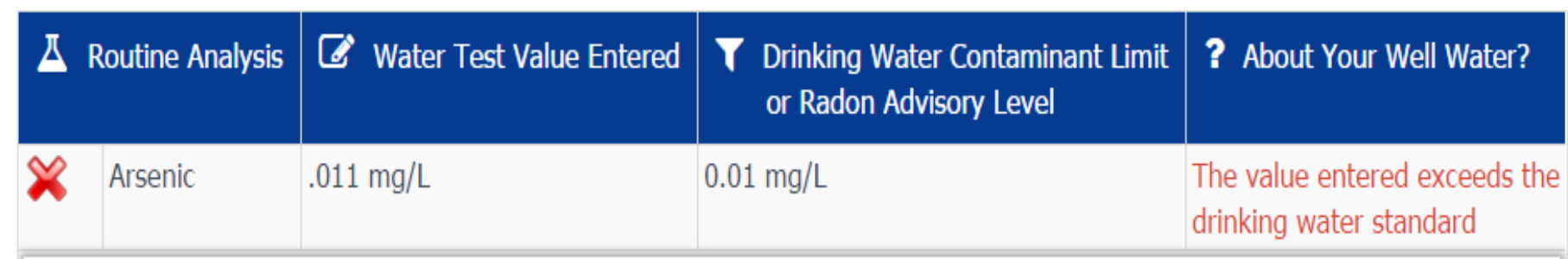

\section{Interpretation of Results:}

Does my well water meet the drinking water standard for arsenic? No, your water does not meet federal and state drinking water standards as it contains more than $0.010 \mathrm{mg} / \mathrm{L}$ of arsenic.

\section{Treatment Options:}

How can I reduce the level of arsenic in my water? In addit system. Install on $0.1 \mathrm{mg} / \mathrm{L}$ of iron and manganese, which must $t$ water:

1. An NSF/ANSI Standard 42 certified whole house oxidizing filter s oxidizing agent to reduce the level of iron and manganese. This alth? Consuming water containing more than $0.010 \mathrm{mg} / \mathrm{L}$ of arsenic is associated with an increased risk of cancer of the skin, badde, (homonal) systems. Your individual health risk as well as diseases of the nerves, lungs, heart, and immune and en water you drink each day, and the number of years you

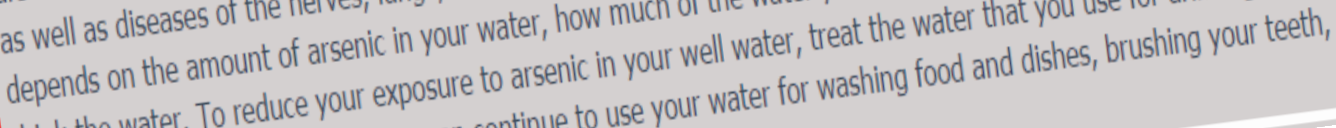
to a level less than $0.010 \mathrm{mg} / \mathrm{L}$. You can

bathing, showering, and for other uses. 


\section{professionals}

Find Certified Water Treatment Professionals

Certified water treatment professionals are individuals who have completed a voluntary credentialing process through wo program tests and certifies only individuals, not dealerships or companies. Certified professionals are typically employed not required for certification.

Professional Designations

Certified Water Treatment Representative (CWR): This designation is best suited for the professional whose job focuses on solving aesthetic water problems.

Certified Water Specialist (CWS): This designation best suited for professionals who provide solutions to "problem water" issues and health-related contaminants.

Certified Installer (CI): This designation is ideal for professionals who specialize

60

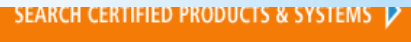

(198:

The Public Health and Safety Organization

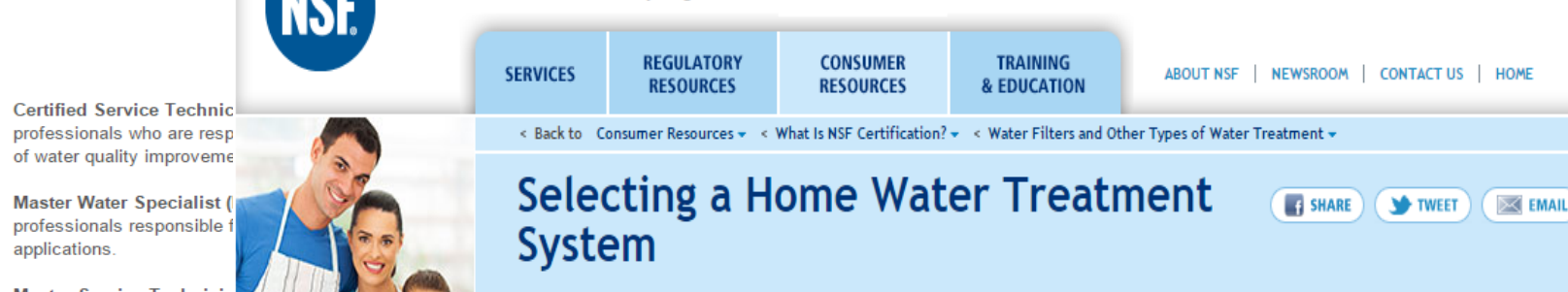

\section{Certified Treatment} products

$$
\text { extension }
$$

Home Resource Areas About Support Us Recent

\section{Home Water Treatment Devices}

Drinking Water and Human Health December 06, 2010 吕 Print

Yweet 00 Pinit $8+1\}$

The table below outlines information on specific home water treatment approaches. Keep in mind that some water treatment can be for aesthetic as well as health factors. If drinking water poses a health risk, the consumer may also consider the cost of purchasing bottled water or tying into a public water system if available as an alternative to treatment. If you need to contact a water treatment professional to install or repair a home treatment system or to assess a problem, be prepared to ask questions that may save you time, money, and frustration in the future.

\begin{tabular}{|c|c|c|}
\hline Device & \multicolumn{1}{|c|}{ Primary Use } & Limitations \\
\hline Activated Carbon & Removes chlorine, volatile & - Does not remove \\
\hline
\end{tabular}

Welcome

extension is an interactive learning environment delivering research-based information emerging from America's land-grant university system.

Select a different institution

P State or Zip

Donate to

Drinling Water and Human Inalth

\section{Treatment background}

\section{duction Need}

be effective for the same group of contaminants. If you have identified a specific Nater that causes you concern, use NSF's contaminant selection guide to locate tified to reduce specific contaminants.

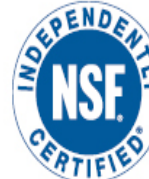

RELATED TOPICS
It can be difficult to determine whether you actually need a water treatment system or what type of in your product selection process. 
3,o0o users Over 17 Months

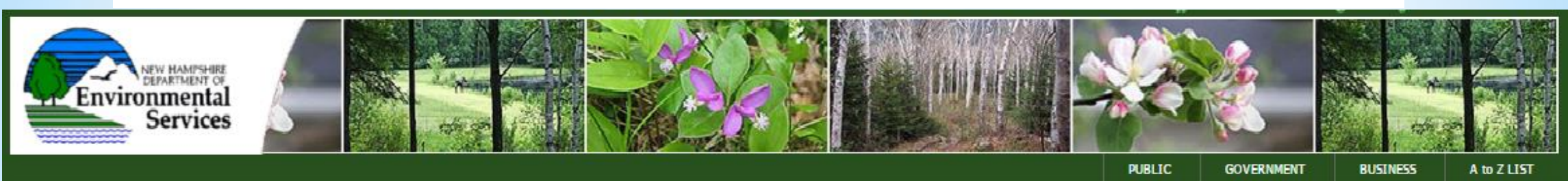

PUBLIC

GOVERNMENT

BUSINESS

\section{The NHDES \\ Be Well Informed Guide}

PROTECT YOUR FAMILY'S HEALTH AND HOME

INFORMATION AND GUIDANCE FOR

TREATING YOUR WELL WATER

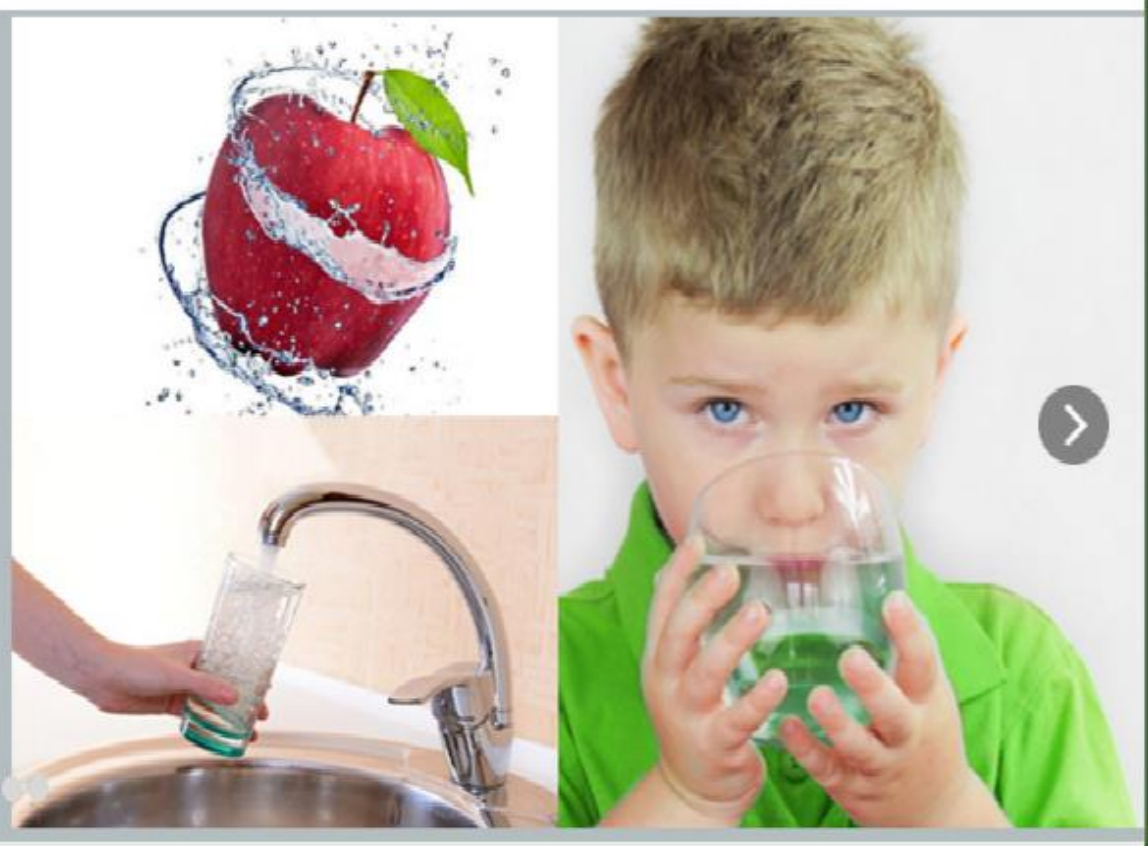

The Be Well Informed Guide from NHDES is designed to help you understand your water test results and, if your well water has commonly found pollutants in it, provide information about health concerns and water treatment choices. New Hampshire is fortunate to have an abundance of clean groundwater, and nearly half of New Hampshire's residents (over 500,000 people) rely solely upon domestic wells (also called "private wells") as their primary source of drinking water. While many private wells provide safe drinking water, certain pollutants like arsenic, iron and manganese are sometimes present in groundwater at levels that can affect your health and home.

NHDES recommends private well owners test their well water every three to five years for pollutants commonly found in New Hampshire's groundwater. This group of commonly found pollutants is listed in the NHDES Private Well Brochure and is referred to as the "Standard Analysis." The Be Well Informed Guide evaluates the pollutants that are part of the Standard Analysis. NHDES recommends that you have your water tested at a NHELAP accredited laboratory. When you have your water tested, your test results will be summarized in the form of a lab report.
DES Private Well Brochure

- Accredited Labs in NH

NHDES Private Well Testing Program

Questions or Comments 


\section{Are you more or less likely to install a water treatment system as a result of using the BWI tool?}

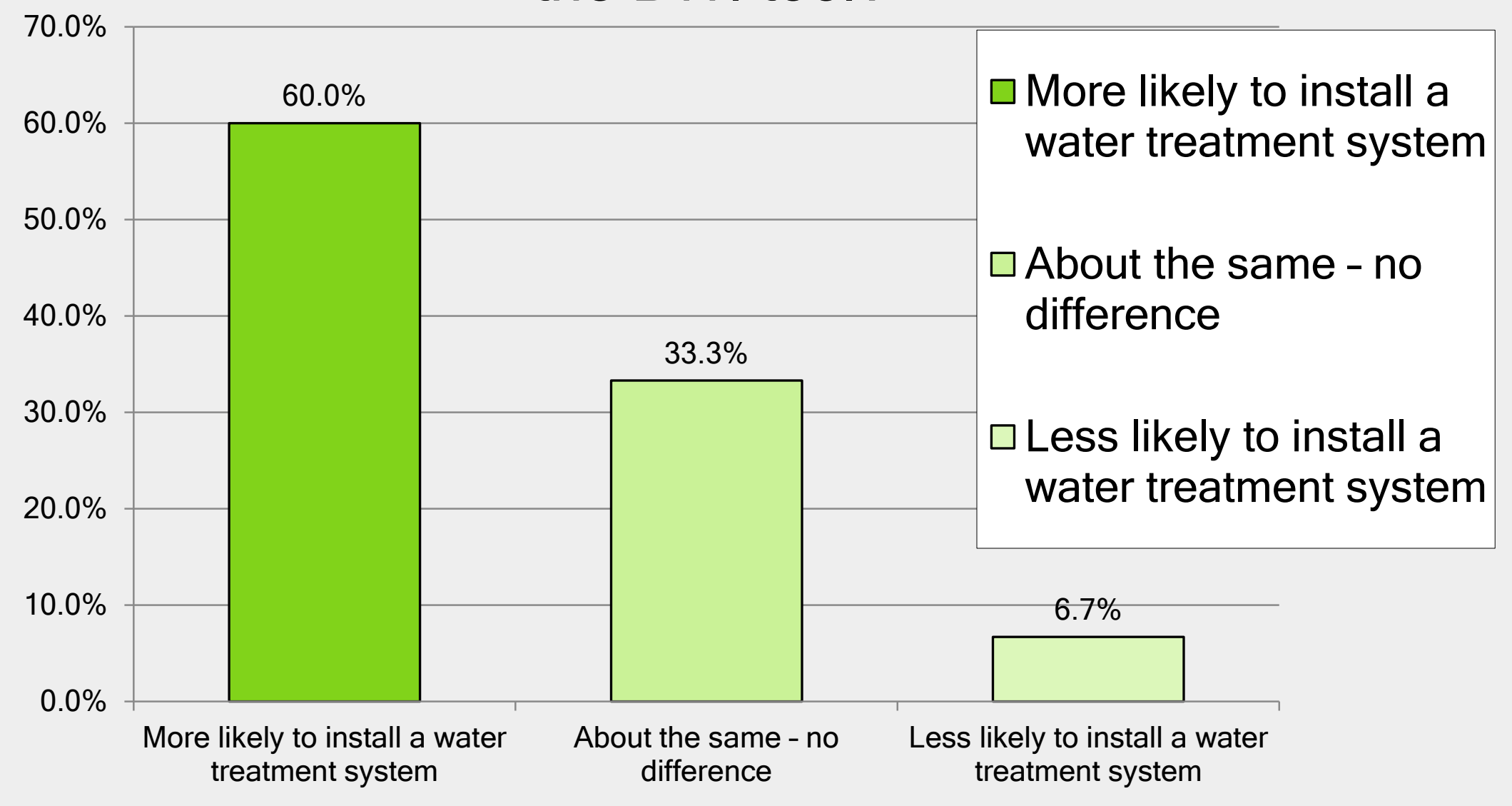

\section{*Suryey Monkey Results}


Has the water treatment system you installed reduced the contaminant(s) in your water to the desired levels?

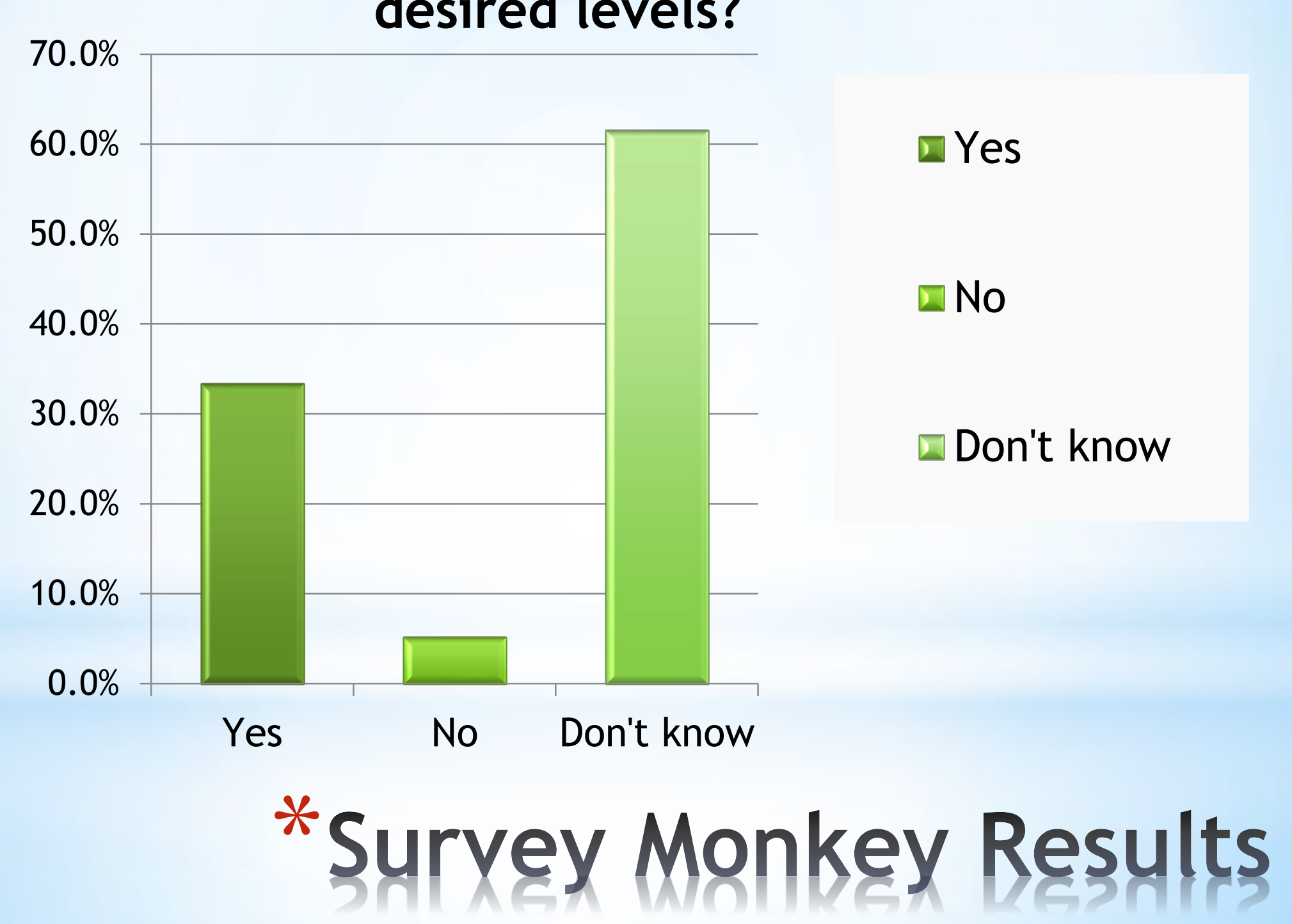




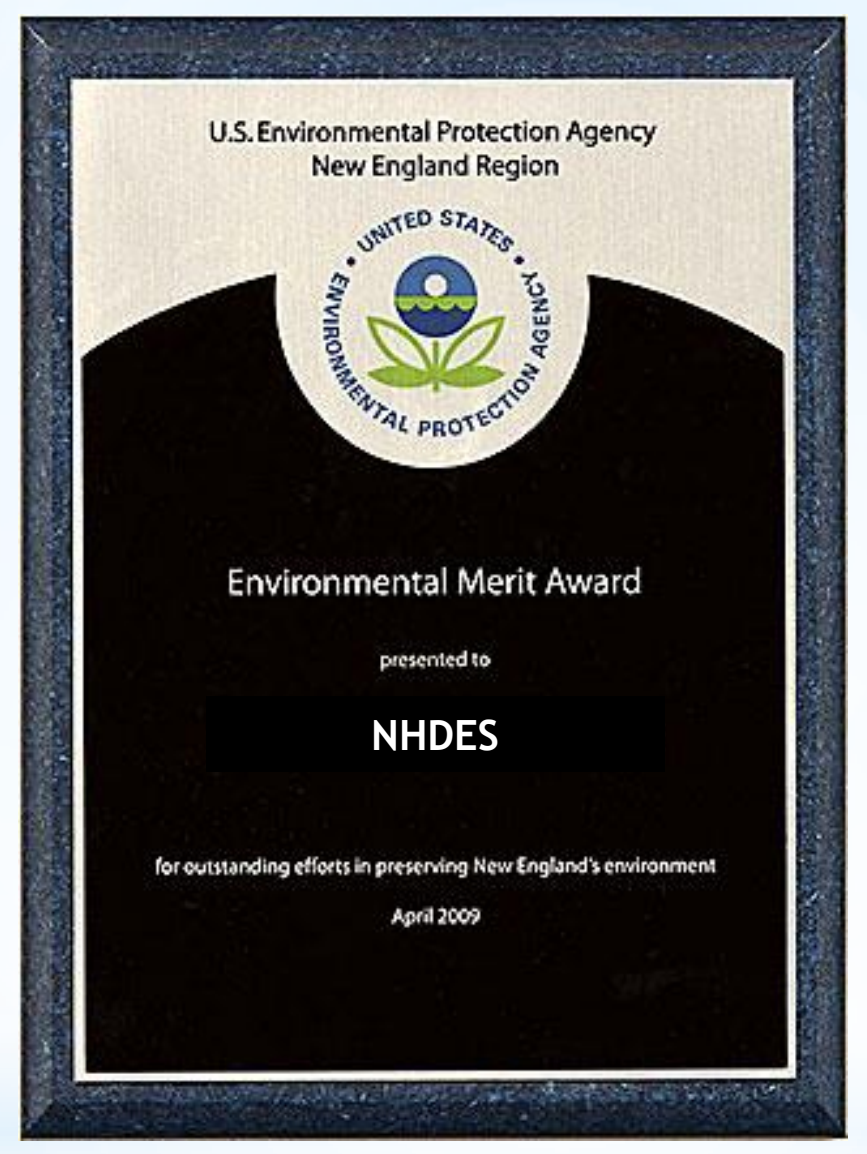

* 2017 EPA Merit Award 
* Minnesota

*Virginia

${ }^{*}$ Massachusetts

*Vermont

* Nevada

*Tennessee

*Lousiana

* Michigan

*North Carolina

*Ohio

${ }^{*}$ Maine

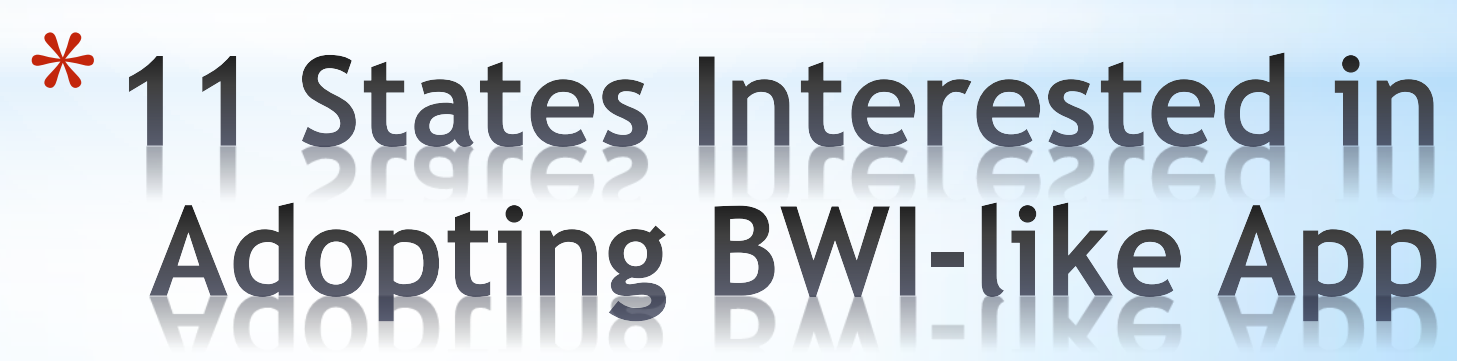


* US Centers for Disease Control

* NH Dept of Health \& Human Services,

Public Health Laboratories

* Toxic Metals Superfund Research Program, Dartmouth College

* United State Environmental Protection Agency 


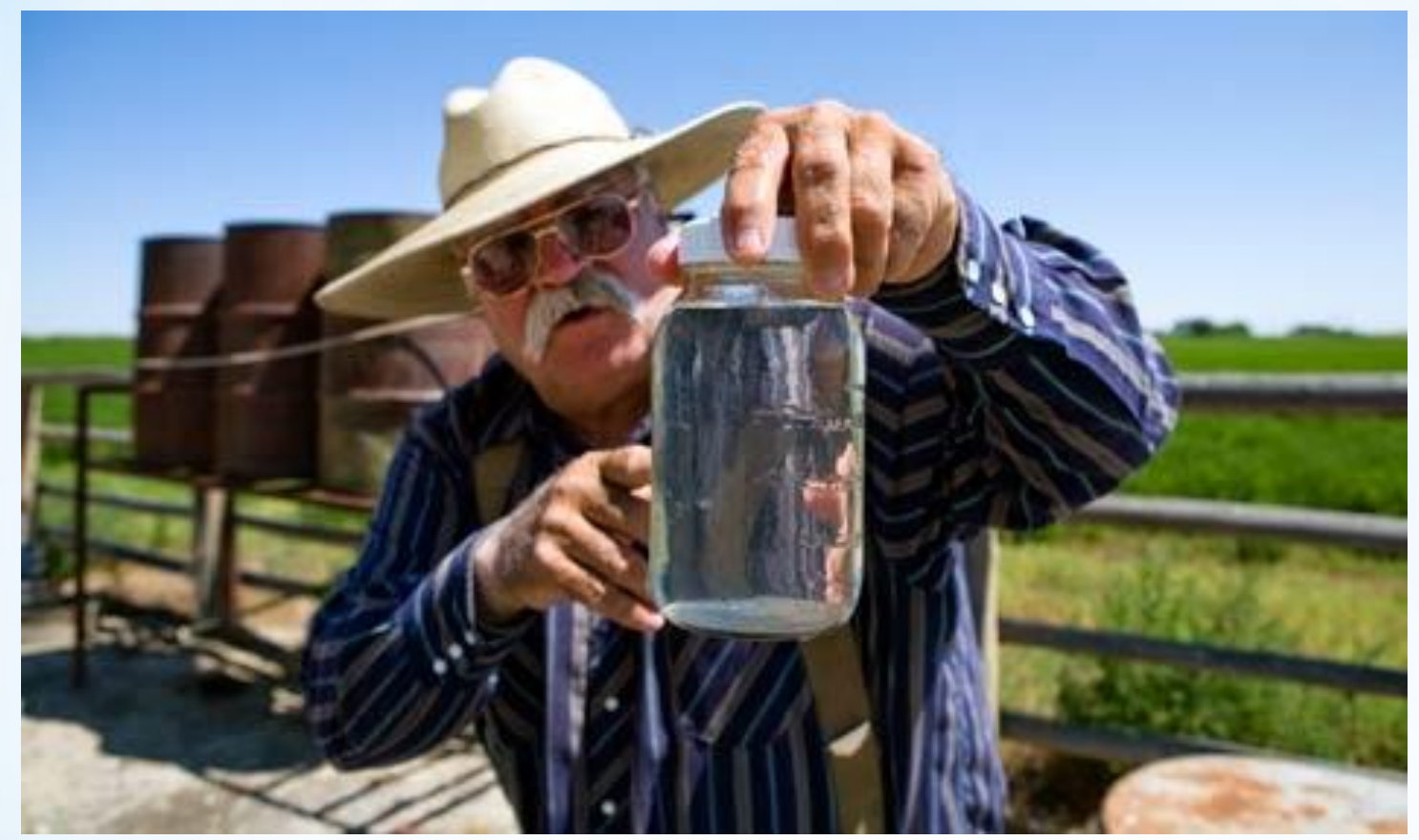

Image Credit, Pro Publica, 2009

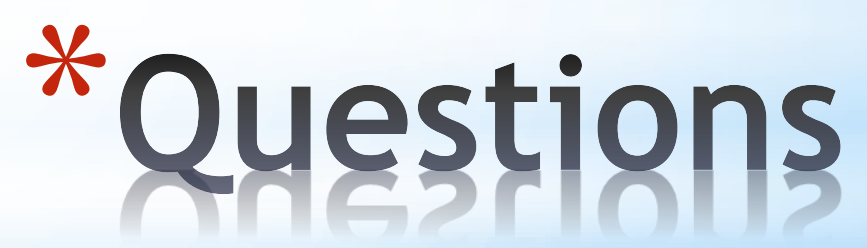

